Klinikal Sains 9 (2) (2021)
JURNAL ANALIS KESEHATAN
KLINIKAL SAINS
UNIIVERSITAS
ABDURRAB

\title{
KEPADATAN JENTIK Aedes aegypti SEBAGAI VEKTOR DEMAM BERDARAH DENGUE (DBD) DI DESA KALIANCAR WONOGIRI
}

\author{
Leona Dwiyan Marahema dan Rinda Binugraheni * \\ Program Studi D III Analis Kesehatan, Fakultas Ilmu Kesehatan, Universitas Setia Budi Surakarta \\ Jl. Letjen Sutoyo, Mojosongo, Kec. Jebres, Kota Surakarta, Jawa Tengah \\ (0271) 852518
}

\begin{tabular}{l}
\hline Info Artikel \\
Sejarah Artikel: \\
Diterima Agustus \\
2021 \\
Disetujui Desember \\
2021 \\
Dipublikasikan \\
Desember 2021
\end{tabular}

Keywords:

Larva Density,

Aedes aegypti,

Dengue

Hemorrhagic Fever

(DHF)

\begin{abstract}
Abstrak
Demam Berdarah Dengue (DBD) adalah sebuah penyakit yang ditularkan oleh dengue virus lewat gigitan nyamuk Aedes sp. Nyamuk tersebut banyak ditemukan diseluruh dunia dan perkembangbiakannya tergolong cepat. Kepadatan jentik atau larva nyamuk merupakan jumlah dari ditemukannya larva atau jentik tersebut dalam tempat perkembangbiakan di suatu wilayah. Kepadatan ini dapat diukur dengan indikator entomologi. Pengukuran kepadatan jentik ini dapat menunjukkan potensi terjadinya KLB pada suatu wilayah. Analisis dilakukan guna memahami kepadatan jentik nyamuk Aedes aegypti di Desa Kaliancar Kecamatan Selogiri Kabupaten Wonogiri. Analisis ini merupakan Analisis observasional (Survey) menggunakan pendekatan cross sectional. Sampel diambil memakai teknik simple random sampling dengan metode single larva. Sampel penelitian ini adalah 100 rumah warga Desa Kaliancar RW 01, RW 03, RW 04 dan RW 05. Hasil penelitian didapatkan nilai HI 20\%, CI 7,22\%, BI 20\%, ABJ 80\% dan DF 3,66. Kesimpulan penelitian ini adalah kepadatan jentik di Desa Kaliancar Kecamatan Selogiri Kabupaten Wonogiri ini tergolong sedang karena nilai DF berada pada skala 3 sampai dengan 4 dengan rata-rata 3,66.
\end{abstract}

Kata Kunci: Kepadatan Jentik, Aedes aegypti, Demam Berdarah Dengue (DBD).

\begin{abstract}
Dengue Hemorrhagic Fever (DHF) is a disease transmitted by the dengue virus through the bite of the Aedes sp. These mosquitoes are found throughout the world and their breeding is quite fast. Density of larvae or mosquito larvae is the number of larvae or larvae found in breeding sites in an area. This density can be measured by entomological indicators. This larval density measurement can show the potential for outbreaks in an area. The analysis was carried out to understand the density of Aedes aegypti mosquito larvae in Kaliancar Village, Selogiri District, Wonogiri Regency. This analysis is an observational analysis (survey) using a cross
\end{abstract}


sectional approach. Samples were taken using simple random sampling technique with single larvae method. The samples of this study were 100 houses of residents of Kaliancar Village RW 01, RW 03, RW 04 and RW 05. The results obtained were HI 20\%, CI 7.22\%, BI 20\%, ABJ 80\% and DF 3.66. The conclusion of this study is that the density of larvae in Kaliancar Village, Selogiri District, Wonogiri Regency is classified as moderate because the DF value is on a scale of 3 to 4 with an average of 3.66 .

Keywords: Larvae Density, Aedes aegypti, Dengue Hemorrhagic Fever (DHF).

(C) 2021

Universitas Abdurrab

Alamat korespondensi: JI Letjen Sutoyo, Mojosongo , Solo

ISSN 2338-4921

Alamat alamat alamat

E-mail: rinda.binurgraheni@setiabudi.ac.id

\section{PENDAHULUAN}

Demam Berdarah Dengue (DBD) yaitu kelainan akibat infeksi virus dengue. Gejala yang dapat terjadi karena infeksi virus ini seperti demam mendadak selama 7 hari yang dengan manifestasi perdarahan, syok dan perdarahan. Penularan virus ini dapat lewat Aedes aegypti yaitu penular utama dari virus tersebut sedangkan Aedes albopictus adalah vektor kedua. Di Indonesia penular utama virus dengue adalah Aedes aegypti (Suhartini et al, 2015). Aedes aegypti betina cukup efektif sebagai penular virus karena sifat dari nyamuk betina yang menghisap darah manusia berulang kali hingga lambungnya penuh. Darah digunakan untuk pematangan telur. Nyamuk ini dapat berkembangbiak dengan cepat terutama pada musim penghujan karena banyaknya genangan air yang tidak terurus. Nyamuk ini dapat hidup dengan baik pada ketinggian kurang dari 1000 mdpl karena suhu pada tempat tersebut cocok untuk perkembangbiakan nyamuk (Dinkes Jateng, 2020). Kepadatan jentik nyamuk adalah jumlah ditemukannya jentik pada tempat perkembangbiakan disuatu wilayah. Perhitungan kepadatan jentik nyamuk ini bertujuan untuk mengetahui banyaknya jumlah rumah yang positif jentik sehingga dapat dilakukan tindakan pencegahan dan penanggulangan penularan kasus (Ramadhani \& Hendri, 2013). Kepadatan jentik tersebut juga digunakan sebagai pantauan potensi terjadinya Kejadian Luar Biasa (KLB) pada suatu wilayah. KLB merupakan peningkatan kasus/ketewasan yang substansial menurut epidemilogi pada masa khusus pada suatu wilayah (Dirjen PP \& PL, 2011). Di Indonesia DBD masih menjadi masalah yang cukup serius sehingga penilaian terhadap kepadatan jentik nyamuk perlu dilakukan. Menurut Kemenkes RI (2020), pada tahun 2019 tercatat 9000 orang terjangkit Demam Berdarah di Jawa Tengah dan sebanyak 123 orang 
meninggal disebabkan virus dengue. 35 Kabupaten di Jawa tengah dilaporkan terjangkit DBD salah satunya Kabupaten Wonogiri (Asmara, 2020). Menurut Dirjen PP \& PL (2020), 6 Kecamatan di Wonogiri endemis Demam berdarah. Endemis adalah munculnya penyakit yang sebelumnya tidak ditemukan pada wilayah tersebut ditentukan berdasarkan kasus yang terjadi selama 3 tahun berturut-turut ditemukan kasus setiap tahunnya (Kemenkes RI, 2017). Tahun 2019 infeksi DBD terbanyak di temukan di wilayah kerja Puskesmas Selogiri dan Wonogiri 2. Peningkatan kasus ditemukan di Selogiri yaitu di Desa Kaliancar (Dinkes Wonogiri, 2020). Peningkatan kasus pada suatu wilayah dapat disebabkan oleh berbagai hal seperti : kepadatan penduduk, faktor geografis, faktor iklim, pengetahuan warga tentang PHBS, faktor lingkungan serta faktor perorangan. Perilaku masyarakat merupakan faktor utama yang dapat mendukung hidup atau perkembangbiakan nyamuk. Kesadaran terhadap PHBS, faktor lingkungan seperti banyaknya penumpukan sampah dan faktor perorangan seperti kebiasaan masyarakat yang suka menggantung pakaian. Hal-hal tersebut dapat mendukung hidup nyamuk yang dilakukan oleh masyarakat sehingga perlu diperhatikan agar kepadatan jentik nyamuk dapat diturunkan (Dinkes Wonogiri, 2020). Analisis dilakukan untuk memahami kepadatan larva nyamuk di Desa Kaliancar agar dapat dilakukan tindakan pencegahan serta penanggulangan. Penilaian Kepadatan jentik dilakukan dengan indikator entomologi yang sudah ditetapkan yaitu House Index (HI), Container Index (CI), Breatue Index (BI) dan Angka Bebas Jentik (ABJ) kemudian dilihat dalam skala Density Figure (DF) 1-9 untuk mengetahui tingkat kepadatan jentik nyamuk (WHO, 2011).

\section{METODE}

Analisis ini adalah analisis yang bersifat observasional (survey) melalui cross sectional. Analisis dikerjakan di Desa Kaliancar Selogiri Wonogiri dalam rentang waktu bulan Maret - Juni 2021. Populasi penelitian ini yaitu rumah warga Desa Kaliancar pada RW 01, RW 03, RW 04 dan RW 05. Sampel penelitian yaitu 100 rumah yang diambil dengan teknik simple random sampling. Sumber penelitian ini yaitu Data Kependudukan di Kecamatan Selogiri dan Data Laporan Pemantauan Jentik secara berkala dari Puskesmas Selogiri.

\section{HASIL DAN PEMBAHASAN}

Survey larva nyamuk Aedes aegypti pada Analisis ini digunakan guna memahami kepadatan populasi nyamuk Aedes $s p$ yang berada di Desa Kaliancar. Jentik ini merupakan bibit dari nyamuk dewasa yang dapat diamati pada sarang nyamuk (Nani, 2017). Menurut Nadesul 
(2016) larva Aedes aegypti jika dibiarkan hidup makan populasi nyamuk pembawa penyakit akan bertambah. Kepadatan jentik nyamuk pada penelitian ini dihitung dengan menggunakan indikator entomologi berikut :

\section{a. House Index $(\mathrm{HI})$}

Tabel 1. Distribusi Jumlah Rumah yang Ditemukan Adanya Jentik

\begin{tabular}{cccc}
\hline No & RW & Rumah diamati & Rumah dengan jentik \\
\hline 1. & 01 & 25 & 6 \\
2. & 03 & 25 & 3 \\
3. & 04 & 25 & 7 \\
4. & 05 & 25 & 4 \\
& Jumlah : & 100 & 20 \\
\hline
\end{tabular}

Sumber : Rekap Hasil Pemeriksaan Jentik Aedes aegypti

Berdasarkan data tabel 1 diperoleh hasil bangunan yang ditemukan adanya jentik sebanyak 20 bangunan dari 100 rumah yang diperiksa. Rumah yang ditemukan adanya jentik paling banyak berada di RW 04 sebanyak 7 rumah dan RW 01 sebanyak 6 rumah sedangkan pada RW 05 rumah yang positif adanya jentik ada 4 rumah dan RW 03 rumah yang positif adanya jentik sebanyak 3 rumah. Berikut perhitungan nilai HI pada penelitian ini :

Jumlah bangunan positif adanya larva

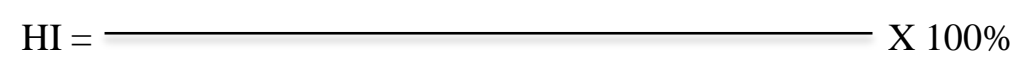

Jumlah bangunan yang diamati

20

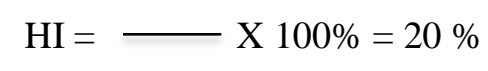

100

Kepadatan jentik nyamuk dilihat dari indikator entomologi House Index (HI) yang menggambarkan banyaknya rumah yang positif jentik. nilai HI pada penelitian ini didapatkan sebesar $20 \%$ melebihi ketentuan dari WHO yaitu $<10 \%$ sehingga rumah-rumah di Desa Kaliancar memiliki potensi sebagai tempat perkembangbiakan nyamuk. Berdasarkan data BPPD (2016) ketinggian wilayah Kaliancar adalah $114 \mathrm{mdpl}$. Wilayah tersebut cocok sebagai tempat perkembangbiakan nyamuk karena nyamuk Aedes aegypti dapat hidup dengan baik pada ketinggian wilayah <1000 mdpl sehingga banyak ditemukan jentik dirumah warga. Selain karena 
ketinggian wilayah banyaknya jentik juga disebabkan oleh jarak rumah masyarakat yang berdekatan mempermudah nyamuk berpindah dan berkembangbiak karena jangkauan terbang nyamuk Aedes aegypti 40-100 m (Kemenkes RI, 2017).

\section{b. Container Index (CI)}

Tabel 2. Distribusi jumlah kontainer

\begin{tabular}{|c|c|c|c|c|c|}
\hline \multirow[t]{3}{*}{ Jenis Kontainer } & \multirow{2}{*}{\multicolumn{2}{|c|}{$\begin{array}{l}\text { Pemeriksaan Jentik } \\
\text { di luar rumah }\end{array}$}} & \multirow{2}{*}{\multicolumn{2}{|c|}{$\begin{array}{l}\text { Pemeriksaan Jentik } \\
\text { di dalam rumah }\end{array}$}} & \multirow{3}{*}{$\begin{array}{l}\text { Jumlah } \\
\text { Kontainer }\end{array}$} \\
\hline & & & & & \\
\hline & $\begin{array}{l}\text { Positif } \\
(+)\end{array}$ & Negatif (-) & $\begin{array}{c}\text { Positif } \\
(+)\end{array}$ & $\begin{array}{c}\text { Negatif (- } \\
)\end{array}$ & \\
\hline Drum & 2 & 18 & - & - & 20 \\
\hline Bak Mandi & - & - & 8 & 95 & 103 \\
\hline Kaleng Bekas & 0 & 6 & - & - & 6 \\
\hline $\begin{array}{c}\text { Pecahan Botol/ Air } \\
\text { Kemasan }\end{array}$ & 1 & 18 & - & - & 19 \\
\hline Ban Bekas & 0 & 4 & - & - & 4 \\
\hline Tempayan & 3 & 18 & 6 & 80 & 107 \\
\hline $\begin{array}{c}\text { Lain-lain (Vas bunga } \\
\text { dan tempat minum } \\
\text { burung) }\end{array}$ & 0 & 9 & 0 & 5 & 14 \\
\hline Jumlah & 6 & 73 & 14 & 184 & 277 \\
\hline
\end{tabular}

Sumber : Rekap Hasil Pemeriksaa Jentik Aedes aegypti

Berdasarkan tabel 2 jumlah kontainer ditemukan adanya jentik lebih banyak pada wadah yang berada di dalam rumah dari 198 jumlah kontainer yang diperiksa ditemukan 14 wadah yang ditemukan adanya jentik. Kontainer yang terdapat di luar rumah jumlah yang positif ditemukan adanya jentik lebih sedikit yaitu ada 6 yang positif dari 79 kontainer yang ada. Jumlah kontainer yang positif ditemukan adanya jentik dari data tabel 3 adalah sebanyak 20 kontainer dari 277 kontainer yang diperiksa. Berikut merupakan perhitungan nilai CI dari penelitian ini :

Jumlah wadah yang ditemukan adanya larva

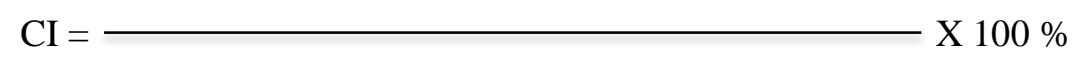

Jumlah wadah yang diamati

20

$\mathrm{CI}=\longrightarrow \mathrm{X} 100 \%=7,22 \%$

277

Kepadatan jentik nyamuk dilihat dari indikator entomologi Container Index (CI) yang menggambarkan banyaknya wadah yang positif jentik. Nilai CI pada penelitian ini adalah sebesar 
7,22\% sudah memenuhi standar yang ditetapkan dimana standar yang ditetapkan untuk CI adalah sebesar <5\% menurut WHO. Menurut Kinansi \& Pujiyanti (2020) besarnya nilai CI dipengaruhi oleh karakteristik kontainer. Karakteristik kontainer yang disukai oleh nyamuk seperti : Bahan pembuatan wadah menurut Ayuningtyas (2013) nyamuk lebih menyukai wadah dengan bahan semen. Letak wadah umumnya wadah yang terletak di dalam rumah lebih disukai nyamuk karena terhindar dari sinar matahari langsung. Warna wadah nyamuk lebih menyukai wadah dengan warna gelap seperti hitam karena memberi rasa nyaman dan tenang saat meletakkan telurnya. Volume air dalam wadah menurut Pancawati et al (2018) volume 1-20 liter berkontribusi meningkatkan kepadatan jentik. Kondisi air umumnya nyamuk lebih menyukai air jernih untuk meletakkan telurnya.

\section{c. Breatue Index (BI)}

Breatue Index (BI) merupakan persentase dari jumlah wadah positif adanya jentik dengan 100 rumah yang diperiksa. Jumlah wadah yang ditemukan adanya jentik dilihat dari tabel 2. Berikut merupakan perhitungan nilai BI dari penelitian ini :

Jumlah wadah yang ditemukan adanya larva

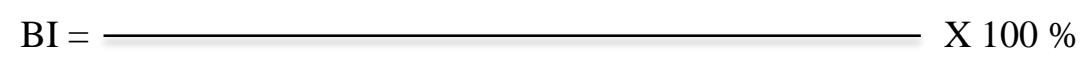

100 bangunan yang diamati

20

$\mathrm{BI}=\longrightarrow \mathrm{X} 100 \%=20 \%$

100

Kepadatan jentik nyamuk dilihat dari indikator entomologi Breatue Index (BI) yang menggambarkan potensi KLB pada suatu wilayah. Nilai BI pada penelitian ini didapatkan sebesar 20\% memenuhi standar yang ditetapkan WHO yaitu sebesar <50\% sehingga Desa Kaliancar tidak berpotensi terjadi KLB. Suatu wilayah dikatakan KLB jika mengalami lonjakan kasus dalam kurun waktu tertentu, dalam hal Demam Berdarah berpotensi KLB BDB jika nilai BI lebih dari $50 \%$.

\section{d. Density Figure (DF)}

Tabel 3. Density Figure Desa Kaliancar Kabupaten Selogiri

\begin{tabular}{lcc}
\hline \multicolumn{1}{c}{ Indikator } & Persentase (Hasil) & Density figure $(\mathrm{DF})$ \\
\hline House Index $(\mathrm{HI})$ & $20 \%$ & 4 \\
\hline Container Index $(\mathrm{CI})$ & $7,22 \%$ & 3 \\
\hline Breteau Index $(\mathrm{BI})$ & $20 \%$ & 4 \\
\hline
\end{tabular}


Tabel 3 merupakan hasil dari perhitungan indikator entomologi. Nilai HI sebesar 20\% berada pada skala DF 4, nilai CI sebesar 7,22\% berada pada skala DF 3 dan nilai BI sebesar $20 \%$ berada pada skala DF 4. Density Figure (DF) merupakan skala yang ditentukan berdasarkan nilai HI, CI dan BI yang sudah dihitung sebelumnya. Nilai DF pada penelitian ini didapatkan sebesar :

$\mathrm{DF}=\frac{4+3+4}{3}=3,66$

Berdasarkan perhitungan nilai Density Figure (DF) tersebut dapat diinterprestasikan hasil DF dibandingkan dengan skala pada tabel DF dengan menunjukkan hasil 3,66. Nilai DF dari penelitian ini adalah pada rentang kriteria kepadatan 3 sampai dengan 4. Nilai tersebut termasuk dalam kriteria kepadatan sedang dengan resiko penularan Demam Berdarah Dengue (DBD) yang juga sedang.

Tabel 4. Skala Density Figure (DF)

\begin{tabular}{ccccc}
\hline $\begin{array}{c}\text { Kriteria } \\
\text { Kepadatan }\end{array}$ & $\begin{array}{c}\text { Density figure } \\
(\mathrm{DF})\end{array}$ & $\begin{array}{c}\text { House Index } \\
(\mathrm{HI})\end{array}$ & $\begin{array}{c}\text { Container } \\
\text { Index }(\mathrm{CI})\end{array}$ & $\begin{array}{c}\text { Breteau } \\
\text { Index }(\mathrm{BI})\end{array}$ \\
\hline Rendah & 1 & $1-3$ & $1-2$ & $1-4$ \\
\hline \multirow{4}{*}{ Sedang } & 2 & $4-7$ & $3-5$ & $5-9$ \\
\cline { 2 - 5 } & $\mathbf{3}$ & $8-17$ & $\mathbf{6 - 9}$ & $10-19$ \\
\cline { 2 - 5 } & $\mathbf{4}$ & $\mathbf{1 8 - 2 8}$ & $10-14$ & $\mathbf{2 0 - 3 4}$ \\
\cline { 2 - 5 } Tinggi & 5 & $29-37$ & $15-20$ & $35-49$ \\
\cline { 2 - 5 } & 6 & $38-49$ & $21-27$ & $50-74$ \\
\cline { 2 - 5 } & 7 & $50-59$ & $28-31$ & $75-99$ \\
\cline { 2 - 5 } & 8 & $60-76$ & $32-40$ & $100-199$ \\
\hline
\end{tabular}

Sumber : (WHO, 1997)

Kepadatan jentik nyamuk disimpulkan dalam skala Density Figure (DF) yang menggambarkan perlunya penanganan lebih lanjut jika didapatkan skala DF tinggi. Nilai DF yang didapatkan dari penelitian ini pada rentang 3 sampai dengan 4 dengan rata-rata 3,66 dimana kepadatan jentik di Desa Kaliancar berada pada kategori sedang.

\section{a. Angka Bebas Jentik (ABJ)}

Tabel 5. Distribusi Angka Bebas Jentik (ABJ)

\begin{tabular}{ccccc}
\hline No & RW & Rumah diperiksa & $\begin{array}{c}\text { Rumah positif } \\
\text { jentik }\end{array}$ & $\begin{array}{c}\text { Rumah negative } \\
\text { jentik }\end{array}$ \\
\hline 1. & 01 & 25 & 6 & 19 \\
\hline 2. & 03 & 25 & 3 & 22 \\
\hline
\end{tabular}




\begin{tabular}{ccccc}
\hline 3. & 04 & 25 & 7 & 18 \\
\hline 4. & 05 & 25 & 4 & 21 \\
\hline & Jumlah : & 100 & 20 & 80 \\
\hline
\end{tabular}

Berdasarkan data tabel 5 didapatkan hasil rumah yang negative atau tidak ditemukan adanya jentik sebanyak 80 rumah dari 100 rumah yang diamati. Rumah yang ditemukan adanya jentik paling banyak berada pada RW 03 sebanyak 22 rumah dan RW 05 sebanyak 21 rumah sedangkan pada RW 01 bagunan negative larva sebanyak 19 buah dan RW 04 rumah yang tidak ditemukan adanya jentik sebanyak 18 rumah. Angka Bebas Jentik (ABJ) didapatkan dari persentase jumlah tempat tinggal negative adanya larva per banyaknya tempat tinggal yang diamati. Berikut perhitungan nilai ABJ pada penelitian ini :

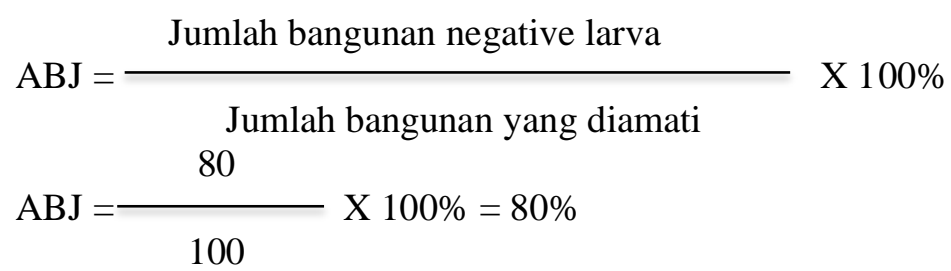

Angka Bebas Jentik (ABJ) dihitung untuk mengetahui banyaknya rumah yang terbebas dari jentik nyamuk. Nilai ABJ pada penelitian ini adalah sebesar $80 \%$ nilai ini kurang dari standar Peraturan Mentri Kesehatan No.50 tentang standar baku mutu kesehatan lingkungan yang menetapkan nilai ABJ standar sebesar 95\%. Semakin rendah nilai ABJ berarti semakin tinggi penyebaran Demam Berdarah pada suatu wilayah. Dilihat dari banyaknya jumlah rumah positif jentik pada perhitungan HI kesadaran masyarakat akan pentingnya Pemberantasan Sarang Nyamuk (PSN) dirasa masih kurang.

Pencegahan dan pemberantasan sarang nyamuk untuk mengurangi perkembangbiakan nyamuk dan mengurangi jumlah kasus yang ada. Kegiatan pemberantasan nyamuk ini dilakukan oleh petugas bersama dengan masyarakat. Peran masyarakat sangat penting dalam kegiatan PSN. Tindakan PSN yang perlu dikerjakan penduduk yaitu 3M: Menguras, Menutup dan Mengubur wadah yang tergenang air. Menguras wadah penampung air contohnya kolam air untuk mandi/WC, tong besi, tempayan dll minimal 7 hari dua kali. Menutup rapat TPA seperti gentong air dan penampung air galon. Menimbun atau ryclicle benda yang sudah tidak digunakan yang mampu menggenang air. Adapun tindakan 3M plus yang dapat dilakukan seperti : Menguras pot tanaman, wadah minum burung, mengganti salura /talang air yang rusak agar air tidak menggenang saat hujan, menutup lubang bambu atau pohon, menggunakan obat larvasida pada area yang susah dibersihkan, mengurangi menumpuk baju, menggunakan lampu standar, memakai bedcanopy dan ramuan pembasmi nyamuk. Pemberantasan Sarang Nyamuk (PSN) juga dapat dilaksanakan dengan menggunakan bahan-bahan kiamia seperti fogging. Fogging ini dapat dilakukan pada seluruh Desa dengan bantuan petugas berwenang (Kemenkes RI, 2017). 


\section{SIMPULAN}

Dapat disimpulkan bahwa kepadatan jentik di Desa Kaliancar Kecamatan Selogiri Kabupaten Wonogiri berada pada kategori sedang dengan nilai Density Figure (DF) berada pada skala 3 sampai 4 dengan rata-rata 3,66.

\section{DAFTAR PUSTAKA}

Asmara, T.(2020)."Sejumlah Kecamatan di Wonogiri Endemis Demam Berdarah". Retrieved januari 23, 2021.from https://timlo.net/baca/87854/sejumlah-kecamatan-di-wonogiriendemis-demam-berdarah/

Badan Perencanaan Pembangunan Daerah.(2016).Kecamatan Selogiri Dalam Data 2016. Wonogiri : Badan Perencanaan Pembangunan Daerah.

Dinas Kesehatan Jawa Tengah.(2020).Waspada Demam Berdarah Dengue (DBD) Saat Musim Hujan. $\quad$ Retrieved 22 januari, 2021.from http://dinkes.jatengprov.go.id/v2018/?s=Demam+berdarah

Dinas Kesehatan Wonogiri.(2020).Buku Profil Kesehatan Kabupaten Wonogiri Tahun 2019.Wonogiri : Dinas Kesehatan.

Direktorat Jendral Pengendalian Penyakit Dan Penyehatan Lingkungan.(2011).Modul Pengendalian Demam Berdarah Dengue.Jakarta : Direktorat Jenderal Pengendalian Penyakit Dan Penyehatan Lingkungan.

Kementerian Kesehatan Republik Indonesia.(2017).Buku Pedoman Penyelidikan Dan Penanggulangan Kejadian Luar Biasa Penyakit Menular Dan Keracunan Pangan (Pedoman Epidemiologi Penyakit).Jakarta : Direktorat Jenderal Pengendalian Penyakit Dan Penyehatan Lingkungan.

Kementerian Kesehatan Republik Indonesia.(2017).Pedoman Pencegahan dan Pengendalian Demam Berdarah Dengue di Indonesia.Jakarta : Direktorat Jenderal Pengendalian Penyakit Dan Penyehatan Lingkungan.

Kementerian Kesehatan Republik Indonesia.(2020).Data dan Informasi Profil Kesahatan Indonesia Tahun 2019.Jakarta : Pusat Data dan Informasi.

Kinansi, R.R., dan Pujiyanti, A.(2020).’Pengaruh Karakteristik Tempat Penampung Air Terhadap Densitas Larva Aedes $s p$ dan Resiko Penyebaran Demam Berdarah Dengue di Daerah Endemis di Indonesia. BACABA, 16(1) : 1-20.

Nadesul, H.(2016).Kiat Mengalahkan Demam Berdarah Dan Virus Zika.Jakarta : PT. Kompas Media Nusantara 4. 
Nani.(2017).'Hubungan Perilaku PSN Dengan Keberadaan Jentik Aedes aegypti Di Pelabuhan Pulau Pisang". Jurnal Berkala Epidemiologi, 5(1) : 1-12.

Pascawati, N.A., Deta, E., Songjanan, E.P., dan Satoto, T.B.T.(2018)."Analisis Faktor Keberadaan Vektor Penular DBD Melalui Identifikasi Tempat Potensial Perkembangbiakan Nyamuk Aedes sp. Di Desa Gergunung Kabupaten Klaten Jawa Tengah. Jurnal Manajemen Kesehatan Indonesia, 6(1): 29-36.

Peraturan Menteri Kesehatan Republik Indonesia Nomor 50 Tahun 2017 tentang Standar Baku Mutu Kesehatan Untuk Vektor dan Binatang Pembawa Penyakit serta Pengendaliannya. Jakarta : Kementrian Kesehatan.

Suhartini, A., Atuti, R., dan Kharisma, Y.(2015).”Survei Kepadatan Jentik Aedes aegypti di Lingkungan Kampus Fakultas Kedokteran Universitas Islam Bandung Tamansari Pada Bulan Maret - Mei 2015". Prosding Pendidikan Dokter. http://dx.doi.org/10.29313/kedokteran.v0i0.1516

World Health Organization.(2011).Comprehensive Guidelines For Prevention And Control Of Dengue And Dengue Haemorrhagic Fever. 